\title{
A CLÁUSULA DE ARBITRAMENTO COMPULSÓRIO DE LITIGIOS, NOS TRATADOS INTERAMERICANOS
}

\author{
José Dalmo Fairbanks Belfort de Matros \\ Professor da Faculdade de Direito da Universida- \\ de de São Paulo - Presidente da Comissão Jurí- \\ dica das "Organizações Não Governamentais" \\ (O.N.U.) - Secção de São Paulo.)
}

\section{INTRODUÇÃO}

Chama-se arbitramento a solução judicial de litígios internacionais, na qual cabe às Partes Conflitantes a escolha do Julgador, a fixação do objeto da sentença, e do processo a seguir, para a sua prolaçã்.

Êstes assuntos são prèviamente acordados, mediante uma convenção preliminar, hoje denominada compromisso arbitral. Nela, figura também a promessa formal das Partes respeitarem o julgado, sejam quais forem os fundamentos. Desde que não ultrapasse os limites que os Estados litigantes houverem por bem tracejar-lhe.

Do exposto deflui : -

a) - que os poderes jurisdicionais dos árbitros dimanam do acôrdo entre os Estados, participantes do litígio;

Tese apresentada à VIII. ${ }^{a}$ Conferência Interamericana de Advogados. 
b) - que o árbitro deve, necessàriamente, ater-se aos termos do compromisso, sendo-lhe defeso julgar extra ou ultra.petita;

c) - cabe às Altas Partes em conflito estabelecer: -

$\left.1^{\circ}\right)$ - o local em que funcionará o julgador;

$2 .^{\circ}$ ) - a matéria a resolver;

$3 .^{\circ}$ ) - as normas formais a seguir;

$\left.4 .^{\circ}\right)$ - o direito aplicável ao caso concreto.

$\mathrm{E}$, por conseguinte: -

d) - o árbitro NÃO JULGA JURE PRÓPRIO. Não goza, como tal, de um poder soberano, salvo nos estritos limites em que os Estados interessados expressamente lhe atribuiram faculdade jurisdicional.

Pouco importa seja êle, eventualmente, um Chefe de Estado (Rei, Imperador, Presidente da República ou Ditador). Sua capacidade julgadora não provirá da soberania interna do seu País. l†em da soberania externa, que o mesmo possa desfrutar.

Não emanará diretamente da Constituição do Estado, nem de sua independência política. Será um poder delegado, transitório e estrito, que se exaure após a publicação do julgado.

Não atinge os Estados Soberanos, extranhos ao litígio, ou que não hajam subscrito o prévio compromisso. Nem poderia o árbitro fazê-lo; pois tais Países não lhe delegaram poderes. Conservaram, íntegra, sua capacidade internacional de agir. Isto é, sua integral soberania.

Por outro lado, a sentença arbitral é irrecorrível. Só pode ser alterada de comum acôrdo, se incursa em êrro de fato (1). $\mathrm{E}$ o vencido sòmente se excusará de cumprí-la, por ato unilateral, caso prove haver o julgamento ultrapassado os poderes conferidos ao árbitro, ex-vi do compromisso arbitral.

1) Sentença arbitral do Rei da Itália, no conflito anglo-brasileiro, relativo às fronteiras da Guiana. 
Devemos, hoje, distinguir o árbitro singular, do coletivo. Ou seja, o Juiz e o Tribunal Arbitral. 0 primeiro é um indivíduo; o segundo, uma Côrte, um Tribunal colegiado.

No primeiro caso, entretanto, quando a escolha recai sôbre um Chefe de Estado, não interessa, via de regra, a identidade física do julgador. Êste mudará, caso venha a extinguir-se o mandato constitucional, conferido ao árbitro primitivo. $\mathrm{E}$ os poderes jurisdicionais transferem-se ao sucessor. (2)

Tal não se verifica, ao contrário, quando a pessôa física, ou jurídica é apontada, em razão de seus conhecimentos técnicos, ou seus dotes individuais.

Cabe, ainda, não confundir :

a) - Os arbitramentos esporádicos, dos permanentes;

b) - Os arbitramentos compulsórios, dos não compulsórios.

Expressões defeituosas, consagradas pela tradição e pelo costume, mas que podem gerar confusões, na prática diplomática.

0 arbitramento se diz esporádico, - caso os Países, que o aceitam, não estejam vinculados, um ao outro, por um tratado permanente de arbitragem.

Se existir tal convênio, êle preverá geralmente as normas processuais a seguir, num arbitramento futuro. Excetuará casos, insusceptíveis de solução arbitral. E estabelecerá, muitas vezes, que a sentença emanará de julgadores, mesmos de um Tribunal Arbitral Permanente.

Mas, mesmo em tal casr., o compromisso específico é necessário, para a designação desses árbitros, para a fixação do objeto da sentença. Para a expressa delegação de poderes, e aceitação prévia do julgado.

O arbitralıento é dito compulsório, caso os Países em fóco hajam assinado um pacto arbitral, contendo a "cláusula de ju-

2) Assim se deu no litígio argentino-brasileiro, referente ao Território das Missões. O julgador, - presidente Cleveland - foi empossado na presidência norte-americana, após a assinatura do compromisso arbitral. 
risdição computsória". Isto é; quando se hajam comprometido, por tratado, a submeter ao julgamento de árbitros, os litigios de determinada categoria ou espécie.

Nesta hipótese, não lhes será lícito eximir-se ao pronunciamento de juizes eletivos. Mas, ainda assim, a jurisdição dêstes conserva seu aspecto delegađo. Pois seu poder jurisdicional emanará, in genere, do tratado em aprêço. E', in specie, do compromisso arbitral, que os houver designado. $\mathrm{E}$ é restrito ao caso pendente.

\section{II. ${ }^{\circ}$}

\section{GENESE HISTóRICA DO ARBITRAMENTO}

O estudo da evolução história revela que a solução arbitral dos conflitos internacionais sòmente será possível, quando haja, entre as Partes Litigantes: -

$10^{\circ}$ ) - igualdade jurídica;

$\left.2 .{ }^{\circ}\right)$ - uma identidade fundamental de cultura;

$\left.3 .{ }^{\circ}\right)$ - um conceito de justiça, baseado num lastro filosófico-religioso comum.

Assim, na Antiguidade Oriental, sòmente se assinalam dois casos embrionários de arbitramento: -

$\left.10^{\circ}\right)$ - o do rei Mislin, de Kish, - chamado a dirimir o conflito de fronteiras entre Ur e Lagash, - durante o primeiro Império Caldáico;

$\left.2 .{ }^{\circ}\right)$ - as sentenças do Super-Rei da Confederação Hitita, a resolver pendência entre os monarcas confederados.

No primeiro caso, os três governantes, que figuram no episódio, não são plenamente soberanos. São "patesi”. Isto é, tributários da Caldéia. Régulos de Estados-títeres, idênticos pela raça, pela religião, pelos padrões de cultura.

E, para melhor impôr o veredictum, o Rei de Kish disse havê-lo recebido em sonhos, ditado pelo mesmo deus, protetor dos três Reinos. 
Entre os Hitidas, o Super-Rei governava agrupamentos autônomos, constituídos do mesmo povo, falando a mesma língua, cultuando os mesmos deuses. Suas sentenças não eram, pròpriamente, as de um árbitro extrangeiro. E sim, de um soberano comum, a evitar choques entre Estados-membros de uma confederação.

$\mathrm{Na}$ Grécia Antiga, a arbitragem floresceu intensamente. Fê-lo, por encontrar um campo preparado: Estados, que eram Cidades, politicamente independentes, mas religiosamente inter-dependentes. Irmanados pelo sangue e pela civilização, pelo culto às mesmas divindades, pelo respeito aos mesmos estetas. Pelo amor à mesma liberdade helênica, que os coligava, nos campos de Platéia, ou nas ribas de Micala, contra a ameaça, vinda do Oriente.

Roma, ao contrário, era a Cidade de vocação imperial. Impossível lhe seria admitir restrições ao seu imperium, submeter seus conflitos ao julgamento de Extrangeiro: Extrangeiro, que seria de início sempre um "hostis". E, mais tarde, um "extrarius".

Assim, os recuperatores, encontradiços na Cidade Eterna, não eram árbitros pròpriamente ditos. Eram cidadãos romanos, encarregados de interpretar, frente ao jus sacrale e ao jus civile, tratados assinados por Roma. Interpretação unilateral.

Seu poder constituia, pois, decorrência do poderio romano; eram magistrados, de competência especial, porém INTERNA pela origem, e pelo direito a aplicar.

Na Idade Média, surge a "Respublica Christiana". Era a Cristandade unida em tôrno do Papa, coesa frente ao Infiel, cimentada pela identidade da Revelação, e pela idéia comum de justiça.

Campo sobremodo propício ao arbitramento, - exercido, vezes sem conta, pelos Reis da Scandinávia, e por Luís IX. ${ }^{\circ}$ de França. Não só dirimindo pendências entre feudatários, - mas também entre a Liga Hanseática e paízes costeiros do Báltico. Ou entre as comunidades autônomas da Flandres. 
O Papa intervinha, então, repetidas vezes, entre os soberanos cristãos. Fazia-o, porém, não pròpriamente a título de árbitro, mas precìpuamente invocando o seu "Poder Apostólico". Poder expressamente relembrado por Bonifácio VIII. ${ }^{\circ}$, ao solver um dissídio entre Felipe IV. ${ }^{\circ}$ (o Belo) e a Côrte de Inglaterra.

Depois... a Renascença, a Reforma, os Estados Nacionais, a irrogar-se soberania ilimitada. E, por três séculos, o esquecimento total do arbitramento...

\section{III. ${ }^{\circ}$}

\section{ORIGENS ANGLO-AMERICANAS DA ARBITRAGEM MODERNA}

Coube inegavelmente aos anglo-americanos reintroduzir a arbitragem internacional, após três séculos de olvídio.

GEORGE A. FINCH assinala a importância histórica do "Tratado Jay", considerando-o o início da era moderna do arbitramento ("The source of modern international law", pg. 91). *- Observação duvidosa, por certo. Refere-se ao "Tratado de Amizade, Comércio e Navegação", assinado entre os Estados Unidos e a Grã-Bretanha, aos 19 de Novembro de 1794.

Buscava-se pôr fim, de jure, à Guerra da Independência. De consagrar, ante a ex-Metrópole, o aparecimento dos Estados Unidos da América, qual Potência soberana. E, ao mesmo tempo, liquidar certas controvérsias de fronteiras, bem como conceder aos "yankees" determinadas facilidades no comércio com as Antilhas Inglesas. Bem assim limitar-lhe o direito de exportar assucar, café, algodão, chocolate e melado para os portos europeus.

Lord Grenvile assinou-o pelo Reino Unido. John Jay firmou-o, na investidura de Enviado Plenipoteciário do govêrno de Washington .

Ora, por duas vezes, êsse convênio prevê a instalação de "comissões", para resolver os litígios pendentes. A primeira, 
traçaria a linha fronteiriça entre os dois Estados signatários; a outra, incumbir-se-ia de examinar e compôr as indenizações, decorrentes do abuso do direito de apresamento. E traçaria o plano para o pagamento das dívidas americanas à Grã Bretanha (3).

É discutível que tal processo contivesse o germen da verdadeira arbitragem. As comissões mixtas assemelhar-se-iam, no primeiro caso, a simples órgãos coletivos de demarcação de fronteiras. E, no segundo, processariam a consultas e julgados, sem a interferência, no entanto, de árbitros extrangeiros, extranhos aos interêsses em conflito.

Mas, já em 1863, o govêrno de Londres propunha ao do Rio de Janeiro resolverem, por via arbitral, a famosa "Questão Christie". E o laudo julgador do Rei Leopoldo da Bélgica era proferido aos 18 de Junho do mesmo ano.

Aos 11 de Julho de 1870, Sir Edward Thorton, Enviado Extraordinário e Ministro Plenipotenciário da Inglaterra em Washington, julgava como árbitro, a pendência americano-brasileira, relativa ao naufrágio da galera "Canadá".

Três anos mais tarde, um tribunal arbitral, formado pelos ministros dos Estados Unidos e da Itália, acreditados no Rio, condenava o Brasil a pagar 38.675 esterlinos a Lord Cochrane. Como liquidação final dos soldos atrazados, que o Conde de Dundonald reclamava do Tesouro do Império.

Finalmente, aos 14 de Setembro de 1872, era solucionado, mediante um laudo de cinco árbitros, o rumoroso caso do "Alabama". E desaparecia, desta forma, aquele grave dissídio entre os Estados Unidos e a Inglaterra. Último resquício internacional, derivado da "Seccession War"...

Nesses quatro últimos casos, a solução foi tìpicamente arbitral. Tratava-se de conflitos externos, resolvidos por juizes

3) Vide Woodrow Wilson - "George VVashington", tradução francesa pág. 228. 
livremente escolhidos pelas Altas Partes Litigantes. Funcionavam mediante "compromisso", firmado pelos Estados-Partes. E tal instrumento fixava a séde do tribunal, sua composição, seu funcionamento e poderes.

Em três questões, a Inglaterra ou os Estados Unidos possuiam interêsses diretos. Na penúltima, os direitos de um súdito britânico constituiam o objeto da questão a solver.

A importância mundial das "Alabama's claims", e a lisura com que a sentença foi executada, deram enorme impulso à idéia de justiça arbitral.

A Grã Bretanha, por seu árbitro nacional, fôra voto vencido na pendência. Mas, ainda assim, cumpriu inteiramente a decisão. Embora fôsse então a Dominadora dos Mares, e a segunda potência militar da Europa.

Grande exemplo, logo imitado pelos demais Países dêste Hemisfério.

212 arbitragens foram realizadas no século XIX. Em 84 delas, assinala MOORE, em seu "Digest", "entre as partes figurava uma Nação Americana". Dêstes 84 litígios, 40 opuzeram Estados Europeus a povos da América. Nos 44 restantes, ambas as Partes em conflito pertenciam ao Novo Continente.

Não é de extranhar, pois, que a Primeira Conferência da $P a z$, reunida em Haia, nos últimos dias do século, haja creado um Tribunal Permanente de Arbitragem, ao qual se filiaram numerosos Estados, de ambas as costas do Atlântico.

\section{IV. ${ }^{\circ}$}

\section{O ARBITRAMENTO NAS CONFERENCIAS INTERAMERICANAS}

Reunira-se, dez anos antes, em Washington, a $1 .^{a}$ Conferência Pan Americana.

A futura O.E.A. intitulava-se, então, apenas um "Escritório Comercial". Figurava, porém, na agenda dos trabalhos, o debate de 
"um acôrdo sôbre um plano definitivo de arbitra"gem, para tôdas as questões, desavenças ou diver"gências, que existissem, ou se pudessem suscitar "entre os diferentes Estados Americanos, afim de "que tôdas as dificuldades e questões entre tais Es"tados pudessem terminar pacificamente, e se evi"tassem guerras".

Previa-se, pois, um pacto continental, unímodo, total. 0 recurso ao arbitramento seria GERAL E COMPULSóRIO. Abrangeria "tôdas as questões, jurídicas ou políticas, monetárias ou territoriais". Fôsse qual fôsse a repercussão que o julgado pudesse ter sôbre a economia ou a vida constitucional dos Estados litigantes.

A prática foi, porém, menos pródiga que o sonho.

Firmou-se um tratado, aos 28 de Abril de 1890. 0 arbitramento era alí proclamado

"princípio de direito internacional americano, para

"a solução de controvérsias ou contendas entre dois "ou mais dêles".

"Excetuavam-se, porém, as questões que, a juizo ex"clusivo de uma das partes em litígio, comprometes"se sua própria independência. Neste caso, o arbi"tramento SERIA FACULTATIVO PARA DITA "PARTE, MAS OBRIGATÓRIO PARA O OUTRO "LITIGANTE" (4).

0 intento pacifista era evidente na Conferência. Proclamava-se "que a guerra é o meio mais cruel, mais incerto, e mais perigoso para decidir as diferenças internacionais".

O arbitramento surgia, então, mais como "solução pacífica" do que na qualidade de acerto judicial de controvérsias.

Não se buscava pròpriamente no árbitro o julgador eleito, mas o dirimidor de conflitos. Isto porque, acentuava alguém nos debates, o momento

4) Accioly - Tratado de derecho internacional público, vol. III. ${ }^{\circ}$ pg. 65. 
"era assaz propício para que se adotasse o arbitra"mento em contraposição às lutas armadas".

Onze Países subscreveram o convênio: Bolívia - Brasil Equador - Estados Unidos - Guatemala - Haiti - Honduras Nicarágua - El Salvador - Uruguai e Venezuela.

Duas resoluções autônomas completavam-no:

$1^{\circ}$ ) - recomendava-se que as controvérsias entre as $\mathrm{Na}$ ções Européias e Americanas "fôssem solucionadas pela mesma maneira amistosa";

$\left.2 .^{\circ}\right)$ - Declarava-se que, "enquanto vigorasse o tratado de arbitramento", não seriam reconhecidas, pelo Direito Internacional Americano, as guerras de conquista. Não se acatasse o fato consumado que delas defluisse, mas fôssem consideradas írritas e nulas quaisquer cessões de território,

"feitas sob ameaça de guerra, ou por imposição de "fôrça armada".

Nenhum valor possuiria, também, para os Estados signatários do convênio, uma renúncia ao arbitramento, extorquida por coação internacional.

Jesus Maria Yepes sauda nesta Convenção o "esboço genial da Pax Americana". Vislumbra nêle, com razão, o germen da "Teoria Stimson do não-reconhecimento". Essa "heresia americana" em direito das gentes, - que seria acolhida pela S.D.N., em 1932.

Entretanto, o prazo previsto para a troca de ratificações expirou, sem que a totalidade dos Estados signatários houvesse aprovado a convenção. Prorrogou-se êste lapso, por mais dois anos, sem melhor resultado.

E, assim, pela aplicação da cláusula "si omnes", o Tratado de 1890 nenhum fruto jurídico produziu.

A Segunda Conferência Pan-Americana reuniu-se no México, em 1902.

Os delegados mostravam-se mais céticos. Desiludidos com a inoperância dos ideais, defendidos doze anos havia. 
O conclave consagrou, simultâneamente, três vias concorrentes, mas contraditórias.

O plenário aprovou um protocolo, pelo qual as Nações Americanas, não signatárias das três convenções de Haia, submetiam-se às normas delas decorrentes. Não por uma adesão direta aos textos, firmados em 1899. Mas de maneira oblíqua, proclamando-os, também, princípios orgânicos do Direito Internacional Americano. Válidos, pois, para todos os Países dêste Continente.

Ora (comenta Yepes) em Haia adotara-se o arbitramento facultativo. $\mathrm{E}$ a adesão de Estados-membros da União Pan-Americana a êste postulado implicava em manifesto recuo, em relação ao resolvido na Conferência de Washington.

Um grupo de Países buscou, porém, combater tal arrefecimento. Firmaram um TRATADO DE ARBITRAMENTO OBRIGATóRIO. Os Estados signatários obrigar-se-iam

"a submeter à decisão de árbitros quaisquer contro"vérsias que existam, ou que venham a surgir entre "êles, e que não possam ser resolvidas por via diplo"mática, SEMPRE QUE, A JUIZO DE QUALQUER "DAS NAÇõES INTERESSADAS, DITAS CON"TROVÉRSIAS NÃO AFETEM NEM A INDE"PENDÊNCIA, NEM A HONRA NACIONAIS".

Um terceiro bloco de Potências subscreveu o "Tratado sôbre reclamações pecuniárias". Neste, as Altas Partes Contratantes estatuiam ser compulsória a arbitragem, em

"tôdas as reclamações, por perdas e danos pecuniá"rios que fôssem apresentadas por seus respectivos "cidadãos, e que não pudessem ser resolvidas amiga"velmente pelos canais diplomáticos, - tôda a vês "que ditas reclamações fôssem de importância sufi"ciente para justificar as despezas com o arbitra"mento".

Êsse último convênio, modificado em 1910, vincula doze Repúblicas Americanas, inclusive o Brasil. (Cfr. - Hildebrando Accioly - "Atos Internacionais", vol. I. ${ }^{\circ}$, pág. 255-226). 
Certo número de Estados não se contentou com os compromissos já existentes. Seus delegados firmaram outros Tratados, em 1906 e 1910, - na $3 .^{a}$ e na $4 .^{a}$ Conferências Interamericanas respectivamente. $\mathrm{E}$ pretenderam incluir, entre as normas vigorantes no Hemisfério, a cláusula do arbitramento compulsório.

Desideratum difícil de atingir.

Apenas nove Estados haviam ratificado a Convenção de Washington: - a Argentina, a Bolívia, a Guatemala, México, Paraguai, Perú, República Dominicana, El Salvador e Uruguai.

O Chile abstivera-se. Os Estados Unidos, fiéis à prática de submeter ao Senado cada compromisso arbitral, para o exame in concreto de suas cláusulas, evitavam vínculos compulsórios.

Maior foi o vácuo após a Conferência do México. E o número de ratificações baixou ainda mais, em face dos acôrdos posteriores.

A atitude do Perú constitui um bom índice dessa tendência à retração. Dí-lo o grande internacionalista ALBERTO ULLôA, em seus "Informes del Assessor Técnico Jurídico", do Ministério de Relações Exteriores, - publicados em 1940.

"Después de haber suscrito la Convención de Mexico "de 1902, y de haberla ratificado, hemos suscrito, "pero no ratificado la de Rio de Janeiro de 1906 y "la de Buenos Aires de 1910, que successivamente "reemplazaron a aquella" (pág. 18).

As razões para tal atitude eram as mais diversas.

Honduras e Nicarágua faziam inserir, em seu tratado de 20 de Outubro de 1894 a "cláusula francesa". Excluiam de arbitramentos futuros assuntos que se ativessem à honra nacional dos Estados signatários.

Cláusula idêntica era encontradiça nos pactos de arbitragem, firmados entre Honduras e Salvador (19-1-1895), Honduras e Guatemala (19-3-95) Costa Rica e Salvador (21-6-1895). E no tratado perú-boliviano, de 1901. 
A Argentina, em célebre "reserva", aposta aos 29 de Dezembro de 1898, excluida do âmbito do arbitramento

"as questões que afetassem princípios constitucionais". E fazia incluir esta cláusula restritiva no Pacto de Arbitragem brasileiro-argentino, de 7 de Setembro de 1905.

Quanto ao governo peruano, atendo-se ao espírito do Decreto de 17 de Abril de 1846, e da Circular, baixada aos 26 de Outubro de 1847, adotava

"una atitud de reserva frente a las convenciones que "espulaban el arbitrage de las reclamaciones por da"nos y prejuicios pecuniarios" (ULLôA - op. cit., pág. 18)

Parecem-lhe, mais ressaltar da disparidade entre a "formulação do direito e sua efetividade", "o aspecto desfavoravel de compromissos arbitrais de caráter geral..."

Tais Países, é claro, dificultosamente poderiam ratificar convênios, como o do México, que tornassem a arbitragem "geral, permanente e obrigatória"...

Dificuldades análogas, igualmente fruto do temor de desprestígio nacional, levariam o delegado brasileiro RUY BARBOSA a regeitar, na Segunda Conferência de Haia, diversos planos de estruturação do Tribunal Permanente de Justiça Arbitral.

Compreende-se, pois, que, ao elaborar, em 1910, seu "Projeto de Código de Direito Internacional Público", EPITÁCIO PESSôA haja consignado que

"a arbitragem obrigatória, para tôdas as questões, "já consagrada em algumas convenções isoladas", não fôra "adotada, ainda, nas deliberações coletivas do Continente".

E, porisso, estatuia, no art. 358 do Projeto:-

"Os Estados submeterão à arbitragem tôdas as con"trovérsias que não tenham podido resolver por ne"gociações diretas, ou outro meio pacífico, desde que "não ponham em causa os seus princípios constitu"cionais". 
Era a adoção (a título de mal menor) da "cláusula argen. tina", que ó autor julgava preferível à "fórmula francesa", por ser mais precisa, mais delimitável.

O Projeto Epitácio Pessôa apresentava, ainda, outra faceta. A arbitragem sòmente se tornaria compulsória, caso falhassem as negociações diretas, e os "outros meios pacíficos".

É sabido que êsse interessante esboço de Codificação não chegou a ser discutido em plenário na $5 .^{a}$ Conferência Pan-Americana. E que perdura, hoje, apenas como trabalho de doutrina.

Essa invocação de "outros meios pácíficos" para a solução de controvérsias iria relegar, aliás, a arbitragem a segundo plano, na $5 .^{a}$ e na $6 .^{a}$ Conferências Pan-Americanas.

Aquela formulou apenas um voto para o progresso sempre crescente "da arbitragem e dos outros meios de solução pacífica". Estudou, de preferência, o estabelecimento de Comissões Internacionais de Inquérito. 0 "Pacto Gondra" deu-lhes consistência e viabilidade.

Na Sexta Conferência, reunida em Havana, os plenipotenciários voltaram-se para outros assuntos de relevância. $\mathrm{E}$ de seus debates surgiu a aprovação do Código Bustamante. E a Convenção do Asilo Diplomático (1928).

Entretanto, adotou uma "resolução", declarando que "as Repúblicas da América adotam o arbitramento "obrigatório como o meio a empregar para a solução "pacífica de suas controvérsias internacionais, DE “CARÁTER JURÍDICO".

$\mathrm{E}$, ao mesmo tempo, convocava uma reunião, a realizar-se em Washington, na qual se desse forma convencional ao aludido princípio.

O TRATADO DE WASHINGTON (1929)

$\mathrm{O}$ conclave reuniu-se em Washington. E dêle resultou 0 Tratado, concluido aos 9 de Janeiro de 1929. 
Estabeleceu-se a obrigatoriedade do recurso à arbitragem, para todos os dissídios internacionais de ordem jurídica. E como tais se consideraram: -

a) - qualquer ponto de direito das gentes;

b) - divergência oriunda da interpretação de um tratado;

c) - todo o fato que, se fôsse comprovado, constituiria uma violação de obrigação internacional;

d) - a apuração da natureza e extensão das reparações, devidas pelo quebrantamento de uma obrigação internacional.

Excluiram-se, apenas, os dissídios precipuamente políticos. Não se excetuaram as questões pecuniárias, nem houve especial ressalva quanto aos conflitos constitucionais.

Essse último aspecto motivou a abstenção da Argentina. Mas, para assegurar ao convênio âmbito deveras continental, assinaram-no os Estados Unidos. Renunciavam, dest'arte, pela primeira vês, ao contrôle prévio dos compromissos arbitrais, por parte do Poder Legislativo.

VITOR DANIEL GOYTIA assim comenta êsse convênio, em artigo publicado no "Boletim de Política Exterior" de Washington. E reproduzido, mais tarde, pela "Revista del Colegio de Abogados de Buenos Aires" (Março|Abril de 1929):

"Os signatários desta Convenção adotaram a famo"sa Cláusula de Opção, estabelecida na organização "da Côrte de Justiça Internacional (de Haia), com "a diferença de que, em logar de ser esta disposição "opcional, e que, por enquanto, de acôrdo com os Es"tatutos da Alta Côrte Internacional, só obriga a de"zesseis Nações, pelo Convênio de Washington pro"cura-se fazer com que seja obrigatória, para mais "vinte Estados Americanos".

A diferença era, porém, mais funda.

"Enquanto que, por aquela Cláusula Optativa, as "Partes podem introduzir casos de exceção, pelo 
"Convênio Americano de Arbitramento, as exceções

"encontram-se indicadas em geral, e só incluem:-

" $\left.1 .^{\circ}\right)$ - as controvérsias que caem sob a jurisdição

"interna das Nações signatárias;

" $\left.2 .^{\circ}\right)$ - as questões que afetem a um Estado, que "não seja parte no Tratado" (op. cit., pág. 46 e segts).

Tais exceções justificavam-se plenamente. A primeira, respeitava a "domestic jurisdiction", — os assuntos pertinentes, de modo precípuo, à competência interna do Estado. A segunda, firmava a tese, outrora levantada pela Chancelaria brasileira, quando da sentença arbitral, entre a Venezuela e a Guiana Inglesa: - a decisão, proferida pelo árbitro não atinge a terceiros Estados, extranhos à pendência.

Para os Países, extranhos ao compromisso arbitral, será sempre uma res inter alios judicata. Nunca um título, oponivel a suas eventuais reivindicações, quer sejam baseadas na ocupação territorial, quer assentes na soberania titulada.

Segundo disposição expressa do acôrdo, - o Tribunal contará cinco Membros, sendo dois árbitros nacionais dos litigantes, e os demais cidadãos de qualquer País americano. A sentença possuirá fôrça obrigatória. Porá fim à disputa definitivamente, e sem apelação.

Alguns Países, presentes à Conferência, firmaram um "Protocolo adicional". Nêle se estabelece um método, pelo qual as Partes em conflito poderiam abandonar, sponte propria, quaisquer reservas ou exceções, por ela opostas normalmente à aplicação da justiça arbitral.

0 tratado de 1929 obteve um bom número de ratificações : - Brasil - Chile - Colômbia - Cuba - República Dominicana Equador - Estados Unidos - México - Nicarágua - Panamá Perú - El Salvador - Uruguai e Venezuela.

Constitui êle, sem dúvida, o esfôrço mais forte e eficaz para a extensão continental do arbitramento. 
Os Convênios Interamericanos que se lhe seguiram pouco aditaram à matéria. Preferiram regulamentar outros métodos, - mais políticos que jurídicos, para o apaziguamento internacional.

Surgiram, então, as consultas, desprovidas de valôr deliberativo. Organizou-se a conciliação, na qual o terceiro interveniente resolve politicamente o dissídio, sem levar em linha de conta decisiva os elementos de jure, que norteariam o árbitro.

Considerável desinteresse pelo arbitramento iriam demonstrar as Conferências de Montevidéo e Lima, - reunidas respectivamente em 1933 e 1938, o Pacto Saavedra Lamas, de 1936, e, mesmo, as Conferências de Consulta de Chanceleres, convocadas durante a $2 .^{\text {a }}$ Conflagração Mundial.

A Conferência Interamericana de Consolidação da Paz, reunida em Buenos Aires, cifrou-se a um voto, recomendando a "adoção dos meios de conciliação e de arbitragem "ampla, ou da justiça internacional para a solução "de tôdas as diferenças ou controvérsias entre as "nações da América, quaisquer que sejam sua natu"reza e origem".

O Ato de Chapultepec reproduziu êsse texto, considerando- o uma das normas integrantes do Direito Internacional Americano (3 de Março de 1945).

Durante a $9 .^{a}$ Conferência Pan-Americana, realizada em Bogotá, foi apresentada a debate a "Carta da O.E.A. Texto que Yepes chama, romanticamente, "Estatuto Orgânico da Pax Americana".

0 Projeto continha, em seu art. 17, referência expressa ao arbitramento internacional. Texto amplo, e mais frouxo do que seria mistér.

Permitia êle que

"a atitude negativa de uma das Partes frustrasse a "obrigação do julgamento arbitral" (Relatório do "Chefe da Delegação do Brasil, pág. 43). 
Violentos debates se travaram, então. 0 delegado Arthur Santos propendia para compromissos mais estritos. As delegações da Colômbia e do México, ao contrário, entendiam ser ampla a jurisdição da Côrte Internacional de Justiça. E admitiam o arbitramento obrigatório

"apenas quando esta se julgasse incompetente" (Relatório citado, página 44).

$\mathrm{O}$ texto, ora vigente, desdobra-se em quatro artigos (20 a 23). E' um compromisso "adotado de forma a permitir que a Carta fôsse assinada sem reservas".

Inclui a arbitragem entre os processos pacíficos para a solução das controvérsias. Deixa, porém, a um tratado especial, o determinar-lhe os casos e o processo a seguir.

Essa Convenção foi assinada logo após. Tomou o nome de "TRATADO AMERICANO DE SOLUÇÕES PACÍFICAS", - ou simplesmente, "PACTO DE BOGOTÁ". (2 de Maio de 1948)

Reduz a arbitragem a mero processo subsidiário. Dedica-lhe o Capítulo V. ${ }^{\circ}$ (arts. 38 a 49) Mas, assim começa a regulá-lo:

"Não obstante o estabelecido no capítulo $4 .^{\circ}$ dês"te Tratado, as Altas Partes Contratantes terão a "faculdade de submeter à arbitragem, SE SE PU"ZEREM DE ACÔRDO NESTE SENTIDO, as di"ferenças de qualquer natureza, sejam ou não jurí"dicas, que hajam surgido ou surgirem subsequen"temente entre elas".

Arbitragem facultativa, pois. E mencionada a contra-gosto, como exceção às normas do capítulo anterior. Ora, considerando que o capítulo IV. ${ }^{\circ}$ versa sôbre o processo judicial, perante um Tribunal de Justiça Internacional, vê-se sem dificuldade, que os negociadores do Pacto de 1948 reputavam a arbitragem mero resíduo de um passado. Mero resquício de uma tradição, há muito superada pelo desenvolvimento atual dos demais processos amistosos. 
$\mathrm{E}$ isto é particularmente grave, se meditarmos que a Carta da O.E.A. se encontra ratificada por tôdas as Repúblicas Americanas, exceto a Argentina e o Uruguai. E que o Pacto de Bogotá conta já com numerosas aprovações, por parte dos povos dêste Continente.

\section{$\mathrm{V} .^{\circ}$}

\section{CRITICA}

0 exame atento dêstes textos leva-nos a crer que a solução arbitral dos conflitos internacionais suscita, atualmente, os seguintes problemas: -

a) - Arbitramento compulsório ou facultativo?

b) - Arbitramento geral, ou restrito a certas categorias de litígios?

c) - $\mathrm{O}$ arbitramento e a soberania estatal.

d) - $\mathrm{O}$ arbitramento e os Tribunais de Justiça' Internacionais.

Essa, a ordem natural das questões. Mas que serão respondidas em sequência diversa, para melhor desenvolvimento do raciocínio.

\section{A)}

\section{O ARBITRAMENTO E A SOBERANIA}

Certos autores dos séculos XVII e XVIII reputavam a solução arbitral incompatível: - a) - com o princípio do "livre exame"; b) - com o caráter soberano das Partes em conflito.

Arguiam alguns adeptos da Reforma, que o Rei, - único julgador de suas intenções, não poderia, sem quebra do livre-exame, submeter a outrem, as decisões de seus problemas espirituais e políticos.

Não criam, aliás, ser possível a um Estado independente acatar a decisão de um órgão jurisdicional extranho, sem alienação tácita de soberania.

Estas manifestações encontram-se, hoje, superadas. 
O árbitro é um julgador. Cabe-lhe decidir se dois ou mais Estados agiram bem ou mal, não em face do fôro íntimo de seus governantes, mas ante a norma objetiva do Direito.

Compete-lhe, como juiz que é, examinar os fundamentos de fato e de jure, das pretenções em debates. $\mathrm{E}$, depois, jus dicere. Aplicar o Direito à situação concreta.

Aliás, na justiça arbitral, os julgadores são livremente escolhidos pelas Altas Partes Litigantes. São elas que atribuem jurisdição ao árbitro, que delimitam, pelo compromisso arbitral, a matéria susceptível de decisão. São elas que estabelecem as normas processuais aplicáveis, e que, por um ato voluntário, assumem a obrigação de cumprir o veredictum.

Há, pois, no caso, uma delegação voluntária e consciente do poder de decidir.

Êste fenômeno, patente nos arbitramentos isolados, é menos visível nos pactos permanentes de arbitragem. Mas continua existindo, embora tal delegação seja prévia, e a escolha só possa recair entre os membros de uma lista, adrede organizada.

Não vemos, também, nesse método de julgamento, qualquer alienação de soberania estatal. 0 árbitro funciona, por nomeação de Estados soberanos, a soberania (total ou parcial) constitui condição sine qua non para alguém ser signatário de um compromisso, ou Parte, numa sentença arbitral.

A decisão condenatória deverá ser cumprida pelo Estado vencido. Sê-lo-á, no entanto, pelo fato de haver sido proferida por um Juiz ou Tribunal, por êle escolhido soberanamente. E em virtude do compromisso, que o Estado subscreveu, e exatamente na qualidade de Pessoa soberana.

Pouco importa que o Árbitro ou Árbitros sejam eventualmente designados por terceiros (Presidente do Conselho da O.A.C.I., por exemplo).

Se-lo-ão, nos têrmos do Tratado, firmado pelas Partes ora em litígio. $\mathrm{E}$ buscarão sua fôrça última, não no ato que os nomeou, mas na ratificação dêsse convênio pelos Estados em litígio. 
B)

\section{ARBITRAMENTO COMPULSÓRIO}

Não vemos, pois, óbice jurídico que impeça um Estado assumir a obrigação compulsória, de levar determinados conflitos ao exame de um árbitro internacional.

Tal proceder apresenta, mesmo, vantagens ponderáveis. Cria um meio permanente de solver os litígios, ainda quando o Tribunal se venha a constituir ex post facto. Impossibilita ao Estado, eventualmente culpado de uma infração ao Direito das Gentes, vir a procurar a irresponsabilidade, abroquelando-se em melindres, verdadeiros ou falsos.

Impede que certos govêrnos, oriundos de revoluções, mais ou menos legítimas, procurem instaurar um regimen completamente oposto às normas de direito internacional.

0 arbitramento facultativo, ao contrário, deixa ao bel-prazer do Estado submeter-se ao não à justiça arbitral. E, como é óbvio, o Tribunal sòmente irá funcionar quando houver boa fé e ânimo pacífico por parte de todos os envolvidos no conflito.

Isto é: quando êste já esteja implicitamente semi-resolvido.

C)

\section{ARBITRAMENTO GERAL OU ESPECIFICO?}

Várias doutrinas defrontam-se nesse debate: -

$\left.1 .^{a}\right)$ - Os Tratados permanentes de arbitragem deverão ater-se, exclusivamente, aos litígios de índole jurídica;

$2 .^{a}$ ) - Deverão êles excluir assuntos que digam respeito à independência ou à honra dos Estados (cláusula francesa);

3. $\left.{ }^{a}\right)$ - Deverá ser excluida de sua competência "qualquer reclamação por danos e prejuizos pecuniários (tese peruana);

$\left.4 .^{a}\right)$ - As disposições constitucionais não ensejam sentença arbitral (fórmula argentina);

5. ${ }^{a}$ - Os Tratados deverão conter uma cláusula de arbitramento compulsório, de âmbito irrestrito.

Examinemo-las, à luz da doutrina, e dos tratados interamericanos. 


\section{$\left.1.0^{a}\right)$}

A primeira escola obteve ganho de causa, por ocasião do Convênio Pan-Americano de Arbitragem (Washington, 1929).

Sòmente as controvérsias de índole jurídica poriam em jôgo a cláusula de arbitramento compulsório. Tal modo de vêr tropeça, no entanto, com grandes dificuldades doutrinárias.

Demonstrou-as, indiretamente, RUY BARBOSA, em célebre debate, durante a Segunda Conferência da Paz.

Separar, em tese, o "jurídico" do "político" é fácil, em direito internacional. Discriminá-los na prática mostra-se por vezes impossível.

A soberania é essencialmente política, embora revista contôrnos jurídicos formais, e se traduza em normas de direito. Políticas, as consequências de auto-determinação dos povos. Políticos, os corolários do direito do Estado ao auto-aperfeiçoamento.

Os tratados de aliança, - instrumentos jurígenos, - são, ao mesmo tempo, armas políticas de considerável alcance.

Jurídico-político é o princípio de não-intervenção. Jurídico-política a "doutrina Stimson do não-reconhecimento", — tal como o são as doutrinas de Tobar e de Drago.

0 problema da agressão econômica, ventilado pelo Chanceler Belt, na IX. ${ }^{\text {a }}$ Conferência Pan-Americana, pode ser formulado em termos de direito. Porém, seu substractum e suas eventuais finalidades escapam ao domínio do jus.

Impossível, pois, formular, com clareza, uma definição que extreme êsses campos contíguos.

A Convenção de Washington (1929) buscou evitar êsse problema. Preferiu a enumeração taxativa das questões reputadas de ordem jurídica.

Tal enumeração, porém, extremamente ampla, considera as controvérsias NÃO POR SUA ESSÊNCIA, mas por sua anti-juridicidade eventual. 
Inclui, pois, entre dissídios jurídicos, divergências políticas em si mesmas, mas abrangendo atos, cujas consequências, por serem ilícitas recairiam sob a sanção do direito das gentes.

\section{$\left.2 . \cdot^{\mathrm{a}}\right)$}

A doutrina francesa exclui do exame arbitral as questões que envolvam a honra e a independência dos Estados.

Mostra EPITÁCIO PESSôA o quanto há de arbitrário, no conceito unilateral de "honra do Estado". Sob êsse pretexto Potências agressivas vêm praticando uma série de atos internacionalmente ilícitos. E impedir o seu exame, em tribunal arbitral, seria, por vezes, acobertar a ilicitude dos "fatos consumados".

Existe, entretanto, nessa escola, uma parte de verdade. Tal se dá ao reconhecer a existência de certos fatos, essenciais à sobrevivência do Estado. Permitir que outrem o prive dêsses elementos vitais, será condenar o País à desaparição como pessôa internacional.

Foi essa hipótese sàbiamente prevista, nas convenções assinadas durante a $1 .^{\mathrm{a}} \mathrm{e}$ a $2 .^{\mathrm{a}}$ Conferências Interamericanas (1890 e 1902).

Urge, porém, encontrar uma definição, ou enumeração taxativa, que mencione tais fatos, mas que evite as interpretações unilaterais. E, respeitando os direitos da outra Parte Conflitante, fuja à elasticidade exagerada.

\section{$\left.3 .^{a}\right)$}

A exclusão dos litígios internacionais, "por danos y prejuicios pecuniarios", preconizada pela Chancelaria peruana, viria a reduzir a quasi nada o âmbito da justiça arbitral.

Mais de cincoenta por cento das questões, até hoje objeto de decisões dessa natureza, ou eram pecuniárias em sua origem. Ou se traduziam em termos de indenização, decorrente da responsabilidade pela prática de ato ilícito internacional. 
Essa verdade é particularmente observável neste Continente. Em especial, por motivo dos danos causados a extrangeiros, durante as guerras civis.

Pecuniárias foram as consequências do caso do "Alabama"; pecuniárias, as indenizações devidas a europeus, lesados durante a "Guerra do Pacífico". Pecuniárias, as reclamações inglesas, contra o Brasil, oriundas do saque dos salvados de uma embarcação britânica, naufragada no litoral do Rio Grande do Sul. ("Questão Christie").

Pecuniários, também, numerosos litígios entre os Estados Unidos e o México, surgidos no curso dos "pronunciamentos" de Huerta, etc.

Tal não impediu que fôssem objeto de laudos arbitrais, nem que as sentenças, adrede proferidas, hajam evitado se eternizasse a tensão internacional.

O que se pode exigir, sem dúvida, é que as reclamações de particulares sòmente sejam encampadas por sua Pátria,

"después de haber recorrido los interessados a los "tribunales de la Republica, donde se les hubiera "retardado o denegado justicia" (Decreto peruano de 1846, ap. Ullôa, op. cit. pág. 18).

$\mathrm{E}$ sòmente então, constituirem objeto de arbitramentos internacionais.

Os créditos, porém, de um Estado extrangeiro, oriundos ex-contractu, ou ex-delicto, dificilmente poderiam escapar ao contrôle dos tribunais arbitrais.

\section{$\left.4 .^{2}\right)$}

A tese argentina é complexa.

Cada País organiza-se internamente em função de sua soberania. Consagra, em textos constitucionais, as normas básicas de sua estructura política, - os poderes dos governantes e os direitos fundamentais dos governados. 
Suponhamos que um litígio internacional venha a levantar-se, envolvendo algum dêsses princípios. Seria o caso susceptível de solução arbitral?

Não, responde a Argentina. Não, redarguiu o III. ${ }^{\circ}$ Reich à S.D.N., em 1938. Não, responderia, por certo, a antiga doutrina americana, segundo a qual "International Law is a part of the law of the land."

A Constituição, sendo a norma suprema de um Direito Positivo Interno, não poderia, segundo tal doutrina, ser derrogada por uma obrigação internacional, que com ela colidisse. Nem objeto de julgamento, por parte de terceiros.

Essa escola vem, no entanto, perdendo terreno, devido a dois fatores essenciais: -

a) - a existência das Constituições analíticas, - contendo não sòmente matéria especificamente constitucional, mas "constitucionalizando" normas de direito civil, preceitos de legislação social, etc.

Tendência já assinalada por Mirkine Guétzévitch. E particularmente visível nas Cartas Magnas, óra vigentes em certos Países da América Latina.

Ora, negar competência à justiça arbitral em casos dessa ordem, seria anulá-la, na prática.

b) - a conceituação dos "direitos fundamentais do Homem", prometidos pela Declaração Universal da O.N.U., e que ora se busca proteger, mediante um convênio.

Se tal Tratado vier a ser assinado, não será lícito às Constituições Nacionais denegar o direito à greve justa, impedir o livre acesso às fontes de informação, dificultar que as esposas acompanhem para fora do País seus maridos extrangeiros, etc.

Em tal caso, a negativa, mesmo fundada em texto da Lei Fundamental do Estado, constituirá ato ilícito internacional. E poderá ser objeto de sentença arbitral.

Existem, entretanto, de maneira inequívoca, assuntos precìpuamente de âmbito interno do Estado, de sua exclusiva com. 
petência. São os que constituem a "domestic jurisdiction", conforme a Carta da O.N.U. (art. $2 .^{\circ}, \mathrm{n} .^{\circ}$ 7)

Tal matéria, regida pelo direito nacional, é óbvio, não pode constituir objeto de decisões arbitrais, sem menocasbo à soberania estatal. Em casos dessa ordem, cabe aos Tribunais do Estado dizerem soberanamente a última palavra. Salvo a hipótese de denegação de justiça.

\section{$\left.5 .^{a}\right)$}

Alguns autores julgam ser o processo de arbitragem incompatível com os compromissos assumidos ante a Carta das Nações Unidas.

Ullôa não chega a tal extremo. Mas julga que

"no debe pectar-se arbitraje cuando está vigente el "Estatuto del Tribunal Permanente de Justicia In"ternacional" (op. cit., págs. 25|26).

Ora, não vemos incompatibilidade alguma entre a Carta de São Francisco e os antigos Tratados de arbitramento.

0 Capítulo VI. ${ }^{\circ}$ do Pacto da O.N.U. prevê "processos para a solução de controvérsias internacionais". A enumeração dêstes meios de apaziguamento é feita em têrmos amplos, gerais, não limitativos.

$A$ arbitragem figura entre êles (art. 33).

$\mathrm{E}$ nem se justificaria que, creada para obter e defender a Paz, e a Justiça, a O.N.U. viesse impedir o funcionamento de métodos pacíficos quaisquer, para atingir a Justiça.

Não vislumbramos, também, dificuldade na coexistência da Côrte Permanente de Arbitragem e do Tribunal de Justiça Internacional.

São jurisdições paralelas; permite-se às Partes recorrer ou a uma ou a outra, ad libitum. Funcionam no mesmo prédio, em harmonia perfeita.

Além disso, numerosos Estados não são membros da 0 . N. U., nem signatários dos Estatutos do T. J. I. Para êstes, a 
justiça arbitral continua a ser a única instância internacional a que possam recorrer.

O mesmo diremos dos Tribunais Arbitrais, que venham a constituir-se, eventualmente, em obediência aos Tratados Interamericanos.

O pan-americanismo é expressamente reconhecido pela Carta da O.N.U., em seu art. 52. Logo, reconhecidos também serão os pactos continentais, que dêle dimanem, - desde que não obstem, de maneira flagrante, os objetivos mundiais das Nações Unidas.

\section{CONCLUSÕES}

A vista do exposto, quer-nos parecer:

a) - Que os acôrdos interamericanos, relativos à arbitragem, firmados em 1890, 1902, 1906, 1910 e 1929 constituiram uma forte contribuição da América para a conservação da Paz, e a obtenção da Justiça, no campo internacional;

b) - que êsses Pactos são perfeitamente compativeis com os compromissos internacionais, decorrentes da Carta das Nações Unidas, bem como da Carta de Bogotá, e mais acôrdos regionais, vigentes no hemisfério Ocidental;

c) - que tais Pactos em nada prejudicam a soberania nacional dos Estados signatários;

d) - que, num tratado interamericano de arbitramento, a ser negociado no futuro, deve ser incluida a cláusula de arbitramento compulsório.

Mas, rias :

e) - devem ser excluidas desta compulsoriedade, as maté-

$\left.1 .^{\circ}\right)$ - que, a juizo de um órgão internacional, comprometem a própria existência ou a independência política dos Estados (5) ;

5) Fonte: - Tratado de Washington (1890) - modificado; 
$2^{\circ}$ ) - as controvérsias que, precìpuamente recaiam sob a jurisdição interna dos Estados (6) ;

$\left.3 .^{\circ}\right)$ - as questões que afetem Estados que não sejam parte no Tratado, e não hajam subscrito o compromisso arbitral (7).

\section{APENDICE}

\section{CASOS ESPECIAIS}

Estudámos, até aqui, os acôrdos interamericanos, especialmente consagrados ao arbitramento internacional.

Outros Pactos existem, no entanto, de âmbito regional ou não, firmados por alguns Estados do Continente Americano, em cujo texto se podem respingar disposições pertinentes a êsse método judicial para solução de controvérsias.

Citaremos exemplificativamente, a Convenção de Chicago, "sôbre aviação civil internacional" (7-12-1944).

O capítulo XVIII prevê um sistema alternativo para dirimir litígios, nascidos da interpretação ou aplicação de seus textos.

A competência originária pertence ao Conselho da 0 . A. C. I. De sua decisão (art. 84),

"qualquer Estado Contratante... poderá apelar pa"ra um Tribunal arbitral ad hoc, em que hajam con"cordado as outras partes da controvérsia, ou para "a Côrte Permanente de Justiça "Internacional".

Tratar-se-ia, à primeira vista, de jurisdição facultativa, a depender do placet do Estado-recorrido. Essa interpretação choca-se, porém, com o artigo imediato.

Se os Estados conflitantes não acordarem quanto à composição do tribunal arbitral, - cada qual nomeará um árbitro. E êstes escolherão um desempatador.

6) Fonte: - Carta das Nações Unidas, art. $2 .^{\circ}$, n..$^{\circ} 7$, - modificado, segundo as sugestões aprovadas pelo II. ${ }^{\circ}$ Congresso Hispano-Luso-Americano de Direito Internacional;

7) - Fonte: - Tratado Interamericano de Arbitramento (Washington, 1929). 
Se naturalmente os fenômenos da vida jurídica pudessem será automàticamente deferida ao Presidente do Conselho, "dentre pessôas qualificadas e disponíveis", constantes de uma lista, prèviamente elaborada (art. 85).

E' clara, pois, a jurisdição compulsória dêsse Tribunal, "que determinará seu próprio regimento interno", e cujas decisões serão definitivas e irrecorrívers. E obrigatórias (art. 86, in fine).

A solução arbitral é, aliás, prevista pelos Tratados aeronáuticos, que se abeberaram na Convenção de Chicago. Entre outros, pelo Acôrdo aéreo anglo-brasileiro, assinado no Rio de Janeiro, aos 31 de Outubro de 1946, e aprovado pelo Poder Legislativo, em 1950.

Dispõe no mesmo sentido o Convênio sôbre Transportes Aéreos, entre o Brasil e a Noruega (assinado a 14-11-47, aprovado pelo Decreto Legislativo 28, de 30-9-48). E mais, o Acôrdo suisso-brasileiro, relativo a Transportes Aéreos Regulares (firmado em Berna, a 10 de Agosto de 1948, aprovado pelo Decreto Legislativo 13 , de 25-3-49).

No mesmo sentido: tratado sueco-brasileiro, de 14-11-47, art. 6. ${ }^{\circ}$, Acôrdo de Paris, com a República Francesa (27-1-47, rt. IX. $^{\circ}$, etc.)

Em todos êsses ajustes, o arbitramento será compulsório, - a menos que as Altas Partes em conflito não escolham outro método para solucionar a divergência.

\section{BIBLIOGRAFIA}

Accioly (Hildebrando) - Tratado de derecho internacional público (tradução espanhola) - Rio, 1946.

Bevilacqua (Clovis) - Direito Público Internacional - $2 .^{\mathrm{a}}$ edição, São Paulo, 1939.

Brown Scott (James) - Vitoria et Suarez (contribution des théologiens au droit international moderne) - Paris, 1939.

Departamento de Estado - Em direção à paz (tradução de documentos de atualidade) - Washington, s/d.

Redslob (Robert) - Les principes du droit des gens moderne - Paris, 1937.

Sanders (William) - 0 direito internacional e a paz internacional na América - Washington, 1940. de la paix - Neufchatel, 1945.

Yepes (Jesus Maria) - Philosophie du panaméricanisme et organization 